Iryna Prykhodko,

$\mathrm{PhD}$ in Economics, Assistant Professor, Ivan Franko National University of Lviv, 19, Sichovykh Striltsiv, Lviv, 79000, Ukraine,

ORCID: 0000-0002-3366-1185;

ResearcherID: V-6261-2017

\title{
FEATURES OF THE «EMOTIONAL» TOURISM FORMATION AND PROSPECTS OF ITS DEVELOPMENT
}

The essence of the «emotional» tourism concept is explored in the article. The types of «emotional» tourism were systematized. It made possible to distinguish the main types of «emotional» tourism: event tourism, «dark» tourism, space tourism, extreme tourism, gastronomic tourism, religious tourism, nostalgic tourism, shopping tours, adventure tourism, hobby tourism, ecotourism, tourism of human addictions and suicidal tourism. The basic directions were revealed and the geographical spread context of the «emotional» tourism types is formulated.

Keywords: «emotional» tourism, space tourism, «dark» tourism, extreme tourism, religious tourism.

Relevance of research topic. The new forms of international tourism emergence are the result of the general concept of active tourism change. The relevance of the study is determined by the need to form a tourism classification, where emotions of curiosity, outrage, dependence, elation, fear etc. are prevailed.

\section{Formulation of the problem.}

There is a methodological problem with the «emotional» tourism classification, because there is no single methodological approach to the typology which can explaine what type of tourism can be attributed to the specific group, in addition, often the same kind can be attributed to several groups at the same time.

\section{Analysis of recent researches and publications.}

Nowadays, more and more information is emerging about new types of tourism, problems and prospects for their development, and many foreign and domestic scientists are interested in this subject.

The issues concerning the extreme tourism dynamic development were raised by such famous scientists as O. Babkin, in. Walk, A. Romanov, Y. Dmitrievsky.

The main aspects of the adventure tourism were explored by such scientists as I. Antonenko, O. Boyko, V. Voskresensky, A. Dubodelova, O. Kuzmin, A. Friedland, S. Fokin, F. Shandor and others. 
A number of scientific publications about space tourism is described by A. Malinovskaya, A. Fedorov, «dark» tourism is outlined in the works of D. S. Chukaev, E. V. Bugriy, M. Foley, J. J. Lemon, P. Stone, R. Sharpley.

The problem of definition and classification of various tourism types is reflected in the scientific works of such scientists as I. V. Zorin, M. P. Malska, V. I. Tsibukha, G. A. Yakovlev, A. A. Romanova, A. V. Ivashchenko and others.

\section{Setting objectives.}

The objectives of the article are:

- to form own authorial definition of the concept of «emotional» tourism;

- to attempt to distinguish the classification of «emotional» tourism;

- to analyze the prevalence of certain types of «emotional» tourism by country.

\section{Presenting main material.}

All types of tourism can be classified according to:

1) benefits for the economy of the country / destination (internal, domestic - as export of services, external - as import of services);

2) trip purpose (cultural, educational, health, business, event, rural, etc.);

3) social and demographic characteristics of consumers (children, youth, family, women, retirement, inclusive, etc.);

4) financing sources (commercial, social, trade union, etc.);

5) transportation methods (automobile, railway, aviation, water, motorcycle, bicycle, pedestrian, equestrian, space, combined, etc.);

6) stay duration (weekend travel, short, long);

7) geographical directions;

8) ordering way of the tour (through real-time consulting with a travel agent or online booking, etc.);

9) subject of the trip organization (organized, amateur, etc.);

10) the number of persons (group, individual, solo tours, selfie tours, etc.);

11) the legality (legal, illegal) [6].

At the end of the 20th century, in 1998 J. Pine and J. Gilmore introduced the impression economy and impression industry concepts. These concepts are now gaining popularity, especially in the travelling and tourism. New markets for the tourist services consumers are characterized by remoteness from traditional cultural and cognitive tourism, and today, one can see the importance of travel process complicity [6].

Non-traditional types of tourism that are exclusive and different from the conventional tourism classification are becoming relevant today. The peculiarity of such tourist services is the receipt of a different emotions range: at the level of personal feelings, at the level of physical feelings, at the level of actions and relationships, as well as at the level of thoughts and memory.

Emotions include both positive and negative aspects of mood: passions, sadness, stress, fear, affection, sublime mood, nostalgia, joy, delight. 
In the economic aspect, the service of «emotional» tourism, the consumer chooses not on the ratio of «price - quality», but on the ratio of «emotions - service», and impressions (emotions) are considered as an independent product.

Thus, «emotional» tourism can be understood as a tourist service (travel journey), which is aimed at creating positive or negative emotions and acute consumer experiences, personal feelings or experiences that are remembered by the individual.

Emotional types of tourist services include: event tourism, «dark» tourism, space tourism, extreme tourism, gastronomic tourism, religious tourism, nostalgic tourism, shopping tourism, adventure tourism, hobby tourism, ecotourism, human addiction tourism and suicidal tourism.

In his study A. V. Ivashchenko notes that today there is a segment of travelers, which are aimed to get their own emotions, impressions and experience. They are not interested in posting photos on social networks or posing in front of friends. It is important for the members of this segment to gain valuable experience, emotions and experiences of their journey. The main importance of these people is not the five-star hotels and the finished tours, but the authenticity, the touch to the traditions of another country. They want to understand and feel another culture, everyday life, are ready to live in uncomfortable conditions, but they will not spare money for any specific excursion or museum [3].

«Black» tourism is one of the unconventional types of tourism. «Black» tourism is a type of cognitive tourism related to the visit of places and objects associated with death (cemetery tourism; catastrophe tourism; mystical tourism; death «tourism»; nuclear tourism [2].

Another type of «emotional» tourism is adventure tourism, which is associated with physical activity and sometimes life-threatening. When organizing such tours, adventures can be specially prepared and provided with all possible security measures. Although adventure tours can include a variety of outdoor activities and even extreme recreation, they are mostly for ordinary people, without special training or outstanding athletic ability. The tourist is also protected from all domestic worries. This makes the adventure tours different from the usual wild tourism. The tour is guided by transport, things in the mountains are carried by porters, meal is made by cooks or the guides. There are also special routes that require experience [7].

There are also fundamentally new tourism types such as gastronomic tourism, tasting tours, dietary, detox tours etc. [3].

According to the World Tourism Organization (UNWTO, Global Report on Food Tourism Research), 79 percent of travelers complete the itinerary by exploring the calendar of gastronomic events and local cuisine [4].

Every third tourist in the world views national cuisine as an important component of travel motivation and about 30 percent of total travel expenses are for food. According to UNWTO research, 88.2 percent of respondents consider gastronomy an important component of the territory's brand. Today, 88.2 percent of respondents view 
gastronomic tourism as a strategic element of the region brand image, and the local cuisine appeal and high service level in catering establishments are the most important motives for buying a home abroad [4].

A shift of priority from «standard» tours in favor of excursions and special programs take place in the demand structure too. Extreme travel is particularly popular: hot air balloons, space expeditions. Space tourism provides the granting of the right to one person or group of people to make space travel. Today, only a few companies provide space tourism services, namely Blue Origin, XCOR Aerospace, Virgin Galactic. It should be noted that the main motive for choosing space tourism is the socio-psychological factors - the desire to know the unknown, improve one's image among the environment, have fun and get new feelings [5].

One can note also the growing popularity of the event tourism - trips to a beer festival, a rock concert by a famous band, a football or tennis match [3].

Another type of «emotional» tourism can be called shopping tourism, which involves trips to other cities and countries for the purpose of shopping in local shops and spending time in shopping and entertainment complexes. Sometimes shopping tours are combined with sightseeing excursions and trips. There are whole «trading villages» or outlet villages in Europe. They sell a variety of quality goods at a price that is much lower than usually, sometimes up to $70 \%$. «Shopping villages» are very popular with both Europeans and tourists alike because of the goods quality, the wide range and the huge discounts [1]. Such tours usually brighten the mood and evoke the positive emotions of tourists.

In the structure of «emotional» tourism it is also possible to distinguish 5 main types of extreme tourism: water tourism, air tourism, mountain tourism, terrestrial tourism and it attracts the attention of new travelers seeking active and risky holidays, as well as fairly new types of «emotional» tourism such as: human tourism addictions, suicidal tourism, ecotourism, etc.

The main types of the «emotional» tourism are presented by figure 1 . In the geographical structure of countries, «emotional» tourism can be represented as follows:

Religious tourism:

- France (Notre Dame de Paris Cathedral, Sacré-Coeur Cathedral, Chartres, Bourget, Lourdes, San Michel);

- Belgium (Holy Blood Movement);

- Italy (St. Peter's Cathedral of the 16th century in Rome, Vatican);

- Bosnia and Herzegovina (pilgrimage to Medjugorje);

- Portugal (pilgrimage to Fatima);

- Turkey (St. Sophia Cathedral in Istanbul, Blue Mosque in Istanbul); 


\begin{tabular}{|c|c|}
\hline \multirow{13}{*}{ 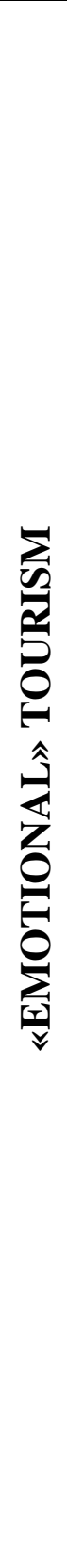 } & \multirow{2}{*}{$\begin{array}{l}\text { «Dark tourism» (ritual places, suicide, places of people death, } \\
\text { technogenic / natural disasters places) } \\
\text { Event tourism (New Year celebrations, carnivals, marriages (on } \\
\text { ice, underwater, during parachute jump), flower exhibitions, } \\
\text { national holidays, sports competitions }\end{array}$} \\
\hline & \\
\hline & Space tourism (flight as an orbital expedition member) \\
\hline & $\begin{array}{l}\text { Extreme tourism (terrestrial - trekking, bicycling, horseback } \\
\text { riding; mountain - climbing, mountaineering, freeraid, caving } \\
\text { and speleotourism; water - shark tours, diving, ice diving, } \\
\text { snorkeling, windsurfing, surfing, kitesurfing, water skiing, } \\
\text { kayaking, whipping rafting, yachting; air - parachuting, } \\
\text { skysurfing, base jumping, ballooning, gliding, hang gliding, } \\
\text { aviation tourism, bungee jumping) }\end{array}$ \\
\hline & $\begin{array}{l}\text { Gastronomic tourism (restaurant visits for gastronomic } \\
\text { masterclasses, gastronomic festivals, cheese / wine / beer / } \\
\text { gourmet tours, farm tours) }\end{array}$ \\
\hline & Religious tourism (pilgrimage) \\
\hline & Nostalgic (place of birth / origin, visiting diasporas) \\
\hline & $\begin{array}{l}\text { Shopping tours (fashion weeks, exhibitions, fashion shows, } \\
\text { fairs, forums) }\end{array}$ \\
\hline & Adventure (Tolkienism, Adventure routes) \\
\hline & $\begin{array}{l}\text { Hobby tourism (art and craft tours, art and craft fairs, art } \\
\text { conferences) }\end{array}$ \\
\hline & $\begin{array}{l}\text { Ecotourism (visiting nature reserves, botanical gardens, national } \\
\text { parks, deserts, closed islands) }\end{array}$ \\
\hline & $\begin{array}{l}\text { Human addiction tourism (drug tourism, sex tourism, alcohol } \\
\text { tourism) }\end{array}$ \\
\hline & $\begin{array}{l}\text { Suicidal tourism (visits to countries where euthanasia is } \\
\text { permitted for general introduction purposes with this } \\
\text { phenomenon) }\end{array}$ \\
\hline
\end{tabular}

Figure 1. Classification of «emotional» tourism

Source: Compiled by author

- Israel (Temple of the Holy Sepulcher, Temple of the Nativity of Jesus, Wailing Wall, Basilica of the Christ Passions).

Gastronomic tourism:

- France (Burgundy - wine tasting, Finn de Claire - oyster tasting);

- Belgium (Beer Museum in Bruges, Museum of Chocolate in Bruges);

- Italy («Tomato Festival», «White Truffle Festival», «EuroChocolate Festival»);

- Hungary (Budapest Wine Festival, World Festival «Ode to Wine» in Pécs, Wine Festival « The feast of the Bull blood» in Eger). 


\section{Event tourism:}

- Germany (Berlin Festival, Love Parade, Reisen International Tourism Fair, Bach Festival, Wagner Festival, Jazz Festival, Festival of Lights and Fireworks, «Oktoberfest»);

- Belgium («Tour de France» stages, «Formula 1» stage, Carnival in Binschet, «La Doudou» in Mons - is celebrated since the sixteenth century in honor of the end of the plague epidemic, flower carpet on the Central Square in Brussels every two years );

- Finland («Ice marathons» on Lake Takho, «Weeks of the Light», World Cup Winter Sports Stages in Lahti, Levi, Ilayas, Himos, Talma);

- United Kingdom (the Royal Regatta, International Music Festival in Llangollen in Wales, Caribbean Festival in Notting Hill, Chelsea Flower Festival);

- Italy («Venice Carnival», «Golden Lion» International Film Festival, «Venice Biennale», Flower Show in Genoa, «Formula 1» competitions, International Fashion Shows in Milan);

- Poland (Chopin Festival).

Ecotourism:

- Austria (especially closed natural areas - Sub-Pannonian dry cereals, Pannonian steppes, Ramsar lands in Styria);

- Italy (Botanical Garden in Padua);

- Israel (Oasis-Gedi Botanical Garden, Ammudey Amram).

«Dark» tourism:

- Romania (Bran Castle (XIV century) known as Dracula Castle, Pelesh Castle (XIX century));

- Ukraine (Molpharism museum (Carpathians), Lychakiv Cemetery in Lviv, Lonsky Prison in Lviv, Holodomor Victims Memorial in Babin Yar, abandoned town of Pripyat);

- Cambodia («Fields of Death»);

- Japan (Hiroshima and Nagasaki);

- Poland (Auschwitz death camps);

- Italy («Island of the Dead»);

- USA (Alcatraz Prison).

Space Tourism:

- USA (Armalillo Aerospace, Orbital Sciences, Space Adventures, Virgin Galactic, Blue Origin - space flights of individuals);

- United Kingdom (Excalibur Almaz - flights around the Moon);

- Japan (Japanese Rocket Society - the beginning of the space tourism development campaign).

Hobby tourism:

- Poland (annual street craft fairs in Poznan);

- Hungary (International days of Folk Art in Sarvar); 
- Turkey (International fairs in Izmir).

Human dependency tourism:

- Netherlands (drug tourism, sex tourism);

- Colombia (sex tourism, drug tourism);

- Czech Republic (beer tourism);

- Germany (beer tourism, alcotourism);

- Brazil, Costa Rica, Cuba, Thailand (sex tourism).

Extreme tourism:

- Zambia («Devil's Pool» at Victoria Falls);

- Bolivia («Road of Death»);

- Chile (bungee jumping into an active volcano);

- USA (swimming with sharks, flying by helicopter over the crater of active volcano, skysurfing, hang gliding, water skiing, speleotourism, freeride);

- Burj Dubai (jumping);

- Alps, Himalayas, Andes (mountaineering);

- Egypt, Maldives, Turkey (diving);

- Australia, Italy (water skiing);

- Brazil, Nepal, Norway (rafting);

- Philippines, Indonesia, Sri Lanka (windsurfing);

- Switzerland (freeriding, skiing).

Suicidal tourism:

- Luxembourg, Netherlands, Switzerland, Belgium (visit to get acquainted with the principle of euthanasia).

Shopping tourism:

- Italy (Milan fashion shows and outlet visits);

- Greece (outlets and shops in Kastoria).

- Nostalgic:

- Canada (living in Ukrainian diasporas);

- Finland (visiting and exploring ethnic lands around Lake Ladoga).

Adventure tourism:

- Sahara Desert (hiking expeditions);

- Slovakia («Fairytale locations» and «Kingdom routes» in Yablunyov village);

- Ukraine («Fairytale routes» in Transcarpathia within the framework of the international «ANTIC» project).

Conclusion. Summarizing the above, it can be affirmed that «emotional» tourism is a multilateral phenomenon aimed at the particular types of tourist consumption services by the individual consumers.

Characteristic features of the «emotional» tourism are its uniqueness, high cost, small number of consumers and dependence on fashionable tourist tendencies. 
It should also be noted that today there is no singular distinct classification of the «emotional» tourism, and therefore the classification presented in the study allows structuring the «emotional» tourism types according to the emotions of the consumer of tourist services.

It is also concluded that different tourism classifications are based on the acquisition of certain emotions by consumers, do not contradict each other, but merely reflect different approaches to the typology of this phenomenon.

\section{REFERENCES}

1. Borovik, S. S. (2019). Shopping tourism as a separate segment of tourism. Looking into the future, Vol. 14(2), pp. 93-97.

2. Glebova, A. A., Zozulya, A. V., Solodovnik, M. A. (2017). The current state and prospects of the development of extreme tourism in Ukraine and the world. Eastern Europe: economy, business and management, Vol. 6(11), pp. 3-8.

3. Ivashchenko, A. V., Postova, V. V. (2017). Modern world tendencies of tourism development. Scientific Bulletin of the Kherson State University, Vol. 23(2), pp. 22-25.

4. Koveshnikov, V.S., Garmash, V. V. (2017). Wine and gastronomic tourism: an important potential for economic development. Investments: practice and experience, Vol. 4, pp. 32-27.

5. Lisova, Y. V. (2017). Jail-tourism: resting in the original. Arguments and facts, Retrieved from: http: // aiftravel / 25530

6. Romanova, A. A. (2017). Types of tourism and their classification in the context of modern trends in the development of tour industry. Economy and region, Vol. 4(65), pp. 13-19.

7. Temnik, I. O., Shcherbakova, N. O. (2016). Tendencies of development of adventure tourism in the world. Economy. Management. Innovation, Retrieved from: http://nbuv.gov.ua/UJRN/eui_2016_4_17 